\title{
UPAYA MENINGKATKAN HASIL BELAJAR PESERTA DIDIK PADA MATA PELAJARAN PENDIDIKAN KEWARGANEGARAAN (PKN) DENGAN MENGGUNAKAN MODEL COOPERATIVE LEARNING TIPE NUMBERED HEADS TOGETHER (NHT) KELAS V-B SD BUDI MURNI 6 MEDAN TAHUN PEMBELAJARAN 2016-2017
}

\author{
OLEH: \\ IMELDA J. SITORUS \\ (PGSD FKIP UNIVERSITAS KATOLIK SANTO THOMAS SU)
}

\begin{abstract}
This research was aimed to (1) Increasing the result of civic education lesson by cooperative learning model numbered heads together (NHT) on student at Fifth grade of SD Budi Murni 6 Medan academic year 2016-2017. (2) Describing problems that faced in applying of cooperative learning model numbered heads together (NHT) in order to increase the result of civic education subject. The subject that did this research was the researcher that collaborated with homeroom teacher as observer meanwhile the object of this research was student at fifth grade of SD Budi Murni 6 Medan totally 37 students that contained 20 male and 17 female. The technique in colleting the data by observation to the result of study test and activity of student's study. The result of the research showed the increase of result of student's study on civic education subject and the material mention organizations within the school and community of on student at fifth grade of SD Budi Murni 6 Medan. This thing proved by the result of research that was done on student's pretest and the student got maximum score amount 6 students $(16,21 \%)$ meanwhile student that had not been achieved amount 31 students $(83,79 \%)$. So the next research was continued on cycle I the student that had been passed the maximum score was 15 students or $40,54 \%$ meanwhile student that had not been passed totally 22 students or $59,46 \%$, so there was an increase on cycle I compared to pretest. But it had not been appropriated the category of completion that had been determined. So it was continued by cycle II and the student got complete score totally 33 students or $89,18 \%$ meanwhile student that had not been passed amount 4 students or $10,82 \%$, so there was an increase on cycle II compared to cycle I and it had been fulfilled the completion that had been determined. Next on cycle I teacher did activity and got averaging amount $60 \%$ and there was an increase to be $88 \%$ on cycle II. Meanwhile the activity of student on learning process got averaging amount $58 \%$ and there was an increase to be $92 \%$ on cycle II. By that mean the conclusion was got that by using cooperative learning model numbered heads together (NHT) on civic education subject by material of mention organizations within the school and community at fifth grade SD Budi Murni 6 Medan Academic Year 2016-2017 could be increase the result of student's study. Therefore it was suggested to use the cooperative learning model numbered heads together (NHT) for the next study in order to increase the student's study.

Keyword : The Result of Student's Study, Civic Education, Cooperative Learning Model Numbered Heads Together (NHT).
\end{abstract}

Volume: 1 No. 1 Juli 2018

JURNAL ILMIAH AQUINAS TERBIT JULI DAN JANUARI SETIAP TAHUNNYA 


\section{PENDAHULUAN}

\section{Latar Belakang Masalah}

Pendidikan sangatlah penting bagi kehidupan semua orang, karena tanpa pendidikan setiap orang tidak akan bisa menulis, membaca, dan berhitung. Pendidikan dapat merubah kehidupan setiap orang menjadi lebih baik.

"Undang-Undang No. 20 Tahun 2003 tentang Sistem Pendidikan Nasional menyatakan bahwa pendidikan adalah usaha sadar dan terencana untuk mewujudkan suasana belajar dan proses pembelajaran agar peserta didik secara aktif mengembangkan potensi dirinya untuk memiliki kekuatan spiritual keagamaan, pengendalian diri, kepribadian, kecerdasan, akhlak mulia, serta keterampilan yang diperlukan dirinya, masyarakat, bangsa, dan negara (Sanjaya, 2011: 1)".

Jean Piaget(Sagala, 2003: 1) mengatakan bahwa, pendidikan berarti menghasilkan, mencipta, sekalipun tidak banyak, sekalipun suatu penciptaan dibatasi oleh pembandingan dengan penciptaan yang lain. Dan selanjutnya mengatakan bahwa pendidikan sebagai penghubung dua sisi, disatu sisi individu yang sedang tumbuh dan disisi lain nilai sosial, intelektual, dan moral yang menjadi tanggung jawab pendidik untuk mendorong individu tersebut. Individu berkembang sejak lahir dan terus berkembang, perkembangan ini bersifat kausal. Namun terdapat komponen normatif, juga karena pendidik menuntut nilai. Nilai ini adalah norma yang berfungsi sebagai penunjuk dalam mengidentifikasi apa yang di wajibkan, diperbolehkan, dan dilarang. Jadi, pendidikan adalah hubungan normatif antara individu dan nilai.

Sebaliknya, Poerbakawatja dan Harahap (Sagala, 2003: 3) mengatakan bahwa "pendidikan meliputi semua perbuatan dan usaha dari generasi tua untuk mengalihkan pengetahuannya, pengalamannya, kecakapannya dan keterampilannya kepada generasi muda sebagai usaha menyiapkannya agar dapat memenuhi fungsi hidupnya baik jasmaniah maupun rohaniah. Artinya pendidikan adalah usaha secara sengaja dari orang dewasa untuk dengan pengaruhnya meningkatkan si anak ke kedewasaan yang selalu diartikan mampu menimbulkan tanggung jawab moril dari segala perbuatannya".

Menurut Burton (Usman, 2010: 6) mengajar merupakan "suatu perbuatan yang memerlukan tanggung jawab morel yang cukup berat. Berhasilnya pendidikan pada siswa sangat bergantung pada pertanggungjawaban guru dalam melaksanakan tugasnya. Mengajar merupakan suatu pekerjaan yang bersifat unik tetapi sederhana. Dikatakan unik karena hal itu berkenaan dengan manusia yang belajar, yakni siswa, dan yang mengajar, yakni guru, dan berkaitan erat dengan manusia didalam masyarakat yang semuanya menunjukkan keunikan. Dikatakan sederhana karena mengajar dilaksanakan dalam keadaan praktis dalam kehidupan sehari-hari, mudah dihayati oleh siapa saja".

Belajar menurut pandangan Skinner (Sagala, 2003: 14) adalah suatu proses adaptasi atau penyesuaian tingkah laku yang berlangsung secara progresif. Belajar juga dipahami sebagai suatu perilaku, pada saat orang belajar, maka responnya menjadi baik. Sebaliknya jika ia tidak belajar, maka responnya menurun. Jadi belajar ialah suatu perubahan dalam kemungkinan atau peluang terjadinya respons. Seorang anak belajar sungguh-sungguh dengan demikian pada waktu ulangan siswa tersebut dapat menjawab semua soal dengan benar. Atas hasil 
belajarnya yang baik itu dia mendapatkan nilai yang baik, karena mendapatkan nilai yang baik ini, maka anak akan belajar lebih giat lagi.

Menurut pendapat peneliti, mengajar dan belajar adalah dua hal yang tidak terpisahkan, guru memang memegang peranan penting dalam pembelajaran di kelas. Tetapi jika tidak ada peserta didik, guru pun tidak ada. Guru tidak bisa mengajar tanpa peserta didik, tetapi peserta didik bisa belajar tanpa ada guru. Itulah sebabnya didalam pendidikan formal guru dengan peserta didik sama-sama saling melengkapi. Peran guru di ruangan kelas bukan hanya menjadi penyaji pelajaran yang akan dipelajari oleh peserta didik, melainkan mengajarkan juga kepada peserta didik tentang cara mempelajari sesuatu dengan efektif. Selain itu, juga harus dapat membimbing dan melatih peserta didik untuk mengembangkan keterampilan yang dimiliki peserta didik tersebut.

"Di dalam UU No. 20 Tahun 2003 Tentang Sistem Pendidikan Nasional (Sisdiknas), peserta didik didefinisikan sebagai setiap manusia yang berusaha mengembangkan potensi diri melalui proses pembelajaran pada jalur pendidikan baik pendidikan formal maupun pendidikan nonformal, pada jenjang pendidikan dan jenis pendidikan tertentu. Peserta didik juga dapat didefinisikan sebagai orang yang belum dewasa dan memiliki sejumlah potensi dasar yang masih perlu dikembangkan. Potensi dimaksud umumnya terdiri dari tiga kategori, yaitu kognitif, afektif, dan psikomotorik (Danim, 2010: 5)"'.

Peserta didik kelas V-B di SD Budi Murni 6 Medan adalah peserta didik yang memiliki berbagai macam karakteristik sesuai dengan pertumbuhannya masing-masing. Karakteristik dari masing-masing peserta didik ini bisa mempengaruhi gaya belajar atau pola belajarnya didalam ruangan kelas, sehingga peserta didik ada yang berhasil dan ada yang kurang berhasil dalam pelajaran.

Peneliti melakukan observasi dengan salah seorang guru di SD Budi Murni 6 Medan, peserta didik yang berhasil dalam mata pelajaran Pendidikan Kewarganegaraan (PKn) materi menyebutkan organisasi di sekolah dan masyarakat tahun pembelajaran 2015-2016, dengan jumlah peserta didik 43 orang, masih jauh dibawah Kriteria Ketuntasan Minimum (KKM) dimana KKM dari mata pelajaran tersebut adalah 80.00 .

Menurut pengamatan peneliti, model yang dipakai guru saat pembelajaran kurang menarik atau mungkin kurang sesuai dengan karakteristik peserta didik, sehingga banyak peserta didik yang kurang aktif dalam proses pembelajaran, peserta didik cenderung tidak mau bertanya saat pembelajaran berlangsung, terlihat dari cara peserta didik yang mengganggu temannya, lemparlempar kertas, dan mengantuk. Padahal materi organisasi di sekolah dan masyarakat sangat menarik untuk dipelajari jika menggunakan alat peraga, media pembelajaran, atau model pembelajaran.

Seluruh rakyat Indonesia memiliki kebebasan untuk berkumpul dan mendirikan organisasi. Kebebasan berorganisasi ini dijamin oleh UUD 1945 dalam pasal 28 dan 28E ayat (3). Dalam pasal 28 UUD 1945 dijelaskan bahwa: "kemerdekaan berserikat dan berkumpul, mengeluarkan pikiran dengan lisan dan tulisan dan sebagainya ditetapkan dengan undang-undang". Dalam pasal 28E ayat (3) UUD 1945 disebutkan bahwa: "setiap orang berhak akan kebebasan berserikat, berkumpul, dan mengeluarkan dan mengeluarkan pendapat". 
Kebebasan berorganisasi adalah bentuk perkumpulan antara dua orang atau lebih yang bekerja sama untuk mencapai tujuan yang sama. Manfaat-manfaat yang didapatkan dalam berorganisasi adalah menambah wawasan dan pengalaman, mengetahui dan mengembangkan bakat, menambah teman, belajar mengemukakan pendapat, belajar menghormati orang lain, belajar menghargai orang lain, mudah bergaul, melatih diri kemandirian, melatih kedisiplinan, membagi dan mengisi waktu dengan kegiatan yang bermanfaat, menimbulkan kepercayaan diri dan tidak mudah mengeluh.

Berdasarkan observasi yang dilakukan peneliti dengan salah seorang guru di SD Budi Murni 6 Medan, maka peneliti mendapatkan data hasil belajar yang diperoleh peserta didik menunjukkan bahwa :

Tabel 1.1 Nilai Ulangan Harian Pendidikan Kewarganegaraan Materi Menyebutkan Organisasi di Sekolah dan Masyarakat Kelas V-B SD Budi Murni 6 Medan Tahun Pembelajaran 2015-2016

\begin{tabular}{|c|c|c|c|}
\hline KKM & Nilai & Jumlah Siswa & Presentase (\%) \\
\hline 80 & $\leq 80$ & 27 & $62,79 \%$ \\
\hline 80 & $\geq 80$ & 16 & $37,21 \%$ \\
\hline Jumlah & & 43 & $100 \%$ \\
\hline
\end{tabular}

Sumber : Hasil Rapor Bulanan di Kelas V-B SD Budi Murni 6 Medan

Berdasarkan tabel diatas, hasil belajar peserta didik kelas V-B SD Budi Murni 6 Medan Tahun Pembelajaran 2015-2016, dengan jumlah peserta didik 43 orang, bahwa perolehan nilai ulangan harian mata pelajaran Pendidikan Kewarganegaraan (PKn) materi menyebutkan organisasi di sekolah dan masyarakat yang tuntas dari 43 orang peserta didik 16 orang $(37,21 \%)$, sedangkan yang tidak tuntas 27 orang $(62,79 \%)$. Maka nilai hasil belajar yang diperoleh peserta didik belum maksimal, karena masih banyak peserta didik yang belum mencapai Kriteria Ketuntasan Minimum (KKM) yang telah ditentukan oleh sekolah yaitu 80 .

Untuk mengatasi hal-hal tersebut hendaknya, guru berusaha menggunakan berbagai macam model pembelajaran misalnya model Cooperative Learning Tipe Numbered Heads Together (NHT). Model ini mampu meningkatkan hasil belajar dari peserta didik karena kelebihan dari model ini yaitu memberikan kesempatan kepada masing-masing peserta didik untuk berbagi ide/gagasan, peserta didik yang mampu akan mengajari peserta didik yang kurang mampu, meningkatkan intensitas kerjasama peserta didik antar kelompok, kebersamaan, dan mempertimbangkan jawaban yang paling tepat dari hasil diskusi kelompok masing-masing. Oleh karena itu, pada penelitian ini peneliti merancang untuk menggunakan model Cooperative Learning Tipe Numbered Heads Together (NHT).

Berdasarkan uraian tersebut, peneliti tertarik melakukan metode Penelitian Tindakan Kelas (PTK) dengan Judul"Upaya Meningkatkan Hasil Belajar Peserta Didik Pada Mata Pelajaran Pendidikan Kewarganegaraan (Pkn) Materi Menyebutkan Organisasi di Sekolah dan Masyarakat dengan Menggunakan Model Cooperative Learning Tipe Numbered Heads Together (NHT)Kelas V-B SD Budi Murni 6 Medan Tahun Pembelajaran 2016-2017”.

Volume: 1 No. 1 Juli 2018 


\section{Identifikasi Masalah}

Berdasarkan uraian yang terdapat pada latar belakang masalah, permasalahan yang dapat diidentifikasi adalah sebagai berikut :

1. Rendahnya hasil belajar peserta didik pada mata pelajaran Pendidikan Kewarganegaraan $(\mathrm{PKn})$ materi menyebutkan organisasi di sekolah dan masyarakat.

2. Guru belum menerapkan model pembelajaran yang variatif dalam proses pembelajaran.

3. Peserta didik kurang aktif saat pembelajaran.

\section{Pembatasan Masalah}

Sesuai dengan identifikasi masalah, masalah dibatasi dan difokuskan pada "Dengan penerapan model pembelajaran Cooperative LearningTipeNumbered Heads Together (NHT),dalam meningkatkan hasil belajar peserta didik pada mata pelajaran Pendidikan Kewarganegaraan $(\mathrm{PKn})$ materi menyebutkan organisasi di sekolah dan masyarakat di kelas V-B SD Budi Murni 6 Medan tahun pembelajaran 2016-2017”.

\section{Rumusan Masalah}

Berdasarkan batasan masalah tersebut, dapat dirumuskan masalah penelitian tindakan kelas sebagai berikut:

1. Apakah dengan menggunakan model Cooperative Learning Tipe Numbered Heads Together (NHT) dapat meningkatkan hasil belajar peserta didik pada mata pelajaran Pendidikan Kewarganegaraan (PKn) materi menyebutkan organisasi di sekolah dan masyarakat pada peserta didik kelas V-B SD Budi Murni 6 Medan tahun pembelajaran 2016-2017?

2. Bagaimana pelaksanaan pembelajaran dengan menggunakan Cooperative Learning Tipe Numbered Heads Together (NHT) pada mata pelajaran Pendidikan Kewarganegaraan (PKn) materi menyebutkan organisasi di sekolah dan masyarakat pada peserta didik kelas V-B SD Budi Murni 6 Medan tahun pembelajaran 2016-2017?

\section{Tujuan Penelitian}

1. Untuk mengetahui dengan menggunakan model Cooperative Learning Tipe Numbered Heads Together (NHT) dapat meningkatkan hasil belajar peserta didik pada mata pelajaran Pendidikan Kewarganegaraan (PKn) materi menyebutkan organisasi di sekolah dan masyarakat pada peserta didik kelas V-B SD Budi Murni 6 Medan tahun pembelajaran 2016-2017.

2. Untuk mengetahui pelaksanaan pembelajaran dengan menggunakan model Cooperative Learning Tipe Numbered Heads Together (NHT) pada mata pelajaran Pendidikan Kewarganegaraan (PKn) materi menyebutkan organisasi di sekolah dan masyarakat pada peserta didik kelas V-B SD Budi Murni 6 Medan tahun pembelajaran 2016-2017.

\section{Manfaat Penelitian}

\section{Bagi guru}

Manfaat yang diperoleh dari penelitian ini adalah sebagai berikut :

Memberi masukan yang bermanfaat bagi tenaga pengajar sebagai motivator, demi peningkatan kualitas pengajar dan dapat menerapkan model pembelajaran kooperatif untuk meningkatkan hasil belajar peserta didik pada materi pokok lain. 


\section{Bagi peserta didik}

Peserta didik memperoleh pengalaman baru cara belajar Pendidikan Kewarganegaraan (PKn) yang lebih efektif, menarik dan menyenangkan serta mudah untuk memahami materi yang dipelajari.

3. Bagi kepala sekolah

Kepala sekolah dapat mensosialisasikan hasil penelitian ini kepada guruguru lain melalui rapat rutin di sekolah demi meningkatkan mutu pendidikan di SD.

4. Bagi sekolah

Diperoleh panduan inovatif model Cooperative Learning Tipe Numbered Heads Together (NHT) yang diharapkan dapat dipakai untuk kelas lainnya dan sebagai bahan meningkatkan kualitas akademik peserta didik khususnya pada mata pelajaran Pendidikan Kewarganegaraan (PKn).

5. Bagi Peneliti

Menambah wawasan dan pengalaman yang sangat berguna tentang keterampilan mengajar dalam meningkatkan hasil belajar peserta didik dan menjadi seorang guru profesional nantinya.

6. Bagi Mahasiswa PGSD UNIKA ST. Thomas

Hasil penelitian ini agar bagi calon guru PGSD menjadi guru yang profesional dan menambah wawasan pengetahuan.

\section{METODOLOGI PENELITIAN Pendekatan dan Metode Penelitian 1. Pendekatan Penelitian}

Dalam penelitian ini, peneliti menggunakan pendekatan campuran. Penelitian pendekatan campuran adalah penelitian yang melibatkan penggunaan dua pendekatan, yaitu pendekatan kuantitatif dan pendekatan kualitatif. Penggunaan dua pendekatan ini dipandang lebih memberikan pemahaman yang lebih lengkap tentang masalah penelitian daripada penggunaan salah satu di antaranya.

Dengan menggunakan pendekatan campuran peneliti dapat memperoleh hasil-hasil statistik kuantitatif dari suatu sampel, kemudian menindaklanjutinya dengan mewawancarai atau observasi sejumlah individu untuk membantu menjelaskan lebih jauh hasil statistik yang diperoleh. Penggunaan dua pendekatan ini dipandang lebih memberikan pemahaman yang lebih lengkap tentang masalah penelitian daripada penggunaan salah satu di antaranya.

\section{Metode Penelitian}

Metode atau jenis penelitian ini menggunakan Penelitian Tindakan Kelas (Classroom Action Research) karena peneliti bertindak secara langsung dalam penelitian, mulai dari awal sampai akhir tindakan. Penelitian ini bertujuan untuk meningkatkan hasil belajar peserta didik pada pelajaran Pendidikan Kewarganegaraan $(\mathrm{PKn})$ dengan menggunakan model cooperative learning tipe Numbered Heads Together (NHT)kelas V-B SD Budi Murni 6 Medan.

Menurut Arikunto dkk (2010: 2-3) "sudah lebih dari sepuluh tahun yang lalu penelitian tindakan kelas dikenal dan ramai dibicarakan dalam dunia pendidikan. Istilah dalam bahasa inggris adalah Classroom Action Research (CAR). Dari namanya sudah menunjukkan isi yang terkandung di dalamnya, 
yaitu sebuah kegiatan penelitian yang dilakukan di kelas". Dikarenakan ada tiga kata yang membentuk pengertian tersebut, maka ada tiga pengertian yang dapat diterangkan.

1. Penelitian: menunjuk pada suatu kegiatan mencermati suatu objek dengan menggunakan cara atau aturan metodologi tertentu untuk memperoleh data atau informasi yang bermanfaat dalam meningkatkan mutu suatu hal yang menarik minat dan penting bagi peneliti.

2. Tindakan: menunjuk pada sesuatu gerak kegiatan yang sengaja dilakukan dengan tujuan tertentu. Dalam penelitian berbentuk rangkaian siklus kegiatan untuk siswa

3. Kelas: dalam hal ini tidak terikat pada pengertian ruang kelas, tetapi dalam pengertian yang lebih spesifik. Seperti yang sudah lama dikenal dalam bidang pendidikan dan pengajaran, yang dimaksud dengan istilah kelas adalah sekelompok siswa yang dalam waktu yang sama, menerima pelajaran yang sama dari guru yang sama pula.

Dengan menggabungkan batasan pengertian tiga kata ini, yaitu (1) penelitian, (2) tindakan, dan (3) kelas, segera dapat disimpulkan bahwa penelitian tindakan kelas merupakan suatu pencermatan terhadap kegiatan belajar berupa sebuah tindakan, yang sengaja dimunculkan dan terjadi dalam sebuah kelas secara bersama. Tindakan tersebut diberikan oleh guru atau dengan arahan dari guru yang dilakukan oleh siswa.

\section{Lokasi dan Waktu Penelitian}

Lokasi yang dijadikan sasaran dalam penelitian ini adalah SD Budi Murni 6 Medan. Terletak di Jln. Pelita V no. 1 Medan Perjuangan. Penelitian ini dilaksanakan dan direncanakan mulai bulan Januari 2017 dari kegiatan persiapan sampai pelaksanaan tindakan yang dilakukan pada semester genap tahun pembelajaran 2016-2017.

\section{Subjek Penelitian}

Dalam penelitian ini subjek yang diambil adalah peserta didik kelas V-B SD Budi Murni 6 Medan yang berjumlah 37 orang peserta didik, yang terdiri dari laki-laki 20 orang dan perempuan 17 orang. Pemilihan subjek ini berdasarkan pertimbangan, hasil wawancara dan observasi dengan guru mata pelajaran Pendidikan Kewarganegaraan (PKn) bahwa masih banyaknya siswa yang kurang aktif saat pembelajaran berlangsung dan rendahnya hasil belajar siswa mata pelajaran PKn.

\section{Jenis dan Sumber Data}

\section{Jenis Data}

Adapun jenis data yang digunakan dalam penelitian ini adalah kualitatif dan kuantitatif.

\section{a. Data Kualitatif}

Data kualitatif lebih menekankan pada proses dan pemahaman secara mendalam terhadap suatu fenomena sosial dan masalah manusia kemudian diuraikan melalui kata-kata. Data kualitatif merupakan data yang diperoleh guru dengan mengamati aktivitas peserta didik pada saat proses pembelajaran di kelas, yang dinilai melalui lembar observasi aktivitas guru dan aktivitas peserta didik. 


\section{b. Data Kuantitatif}

Suatu metode penelitian yang bersifat induktif, objektif, dan ilmiah, serta data yang diperoleh berupa angka atau pernyataan yang dianalisis untuk menemukan keterangan mengenai apa yang ingin kita ketahui. Data kuantitatif merupakan data yang diperoleh oleh guru berupa hasil pengukuran dari soal tes yang dikerjakan oleh setiap peserta didik yang diakumulasikan dalam bentuk nilai.

\section{Sumber Data}

1. Informan atau narasumber, yaitu guru mata pelajaran Pendidikan Kewarganegaraan (PKn) kelas V dan peserta didik kelas V SD Budi Murni 6 Medan.

2. Tempat dan peristiwa berlangsungnya aktivitas pembelajaran Pendidikan Kewarganegaraan (PKn), dalam hal ini SD Budi Murni 6 Medan.

3. Dokumen daftar nilai mata pelajaran Pendidikan Kewarganegaraan (PKn) kelas V SD Budi Murni 6 Medan.

\section{Teknik dan Alat Pengumpulan Data}

\section{Observasi}

Pengumpulan data melalui observasi dilakukan sendiri oleh peneliti dan juga dibantu oleh guru yang berkedudukan sebagai guru kelas dan dilakukan pada kelas yang dijadikan sampel, yaitu untuk mengetahui sejauh mana peningkatan aspek afektif dan psikomotorik pada peserta didik dan untuk mengetahui bagaimna cara guru menggunakan strategi berbasis masalah dalam proses pembelajaran. Kemudian mengisi angket tentang aktivitas guru dan juga aktivitas peserta didik.

\section{Tes}

Pengumpulan data melalui tes dilakukan sendiri oleh peneliti pada kelas yang dijadikan sampel, yaitu untuk melihat kemampuan peserta didik dalam menjawab soal-soal yang berhubungan dengan kebebasan berorganisasi setelah mendapat tindakan. Ini juga dilakukan untuk mengukur ketercapaian indikator yang disampaikan oleh peneliti.

Tes yang diberikan sesuai dengan indikator yang hendak dicapai dan instrumen dalam penelitian ini adalah evaluasi hasil belajar secara kognitif yaitu aspek pengetahuan $(\mathrm{C} 1)$, pemahaman $(\mathrm{C} 2)$, penerapan $(\mathrm{C} 3)$.

\section{Uji Validitas Data \& Instrumen}

Validitas berkenaan dengan ketetapan alat penilaian terhadap konsep yang dinilai sehingga betul-betul menilai apa yang seharusnya dinilai Sudjana (2009: 12).Agar instumen yang dibuat oleh peneliti dapat dikatakan valid maka dilakukan uji validitas. Validitas dalam penelitian ini dilakukan dengan diuji dan diperiksa validitasnya, sehingga data tersebut dapat dipertanggungjawabkan. Untuk menjamin validitas ini maka semua pertanyaan disusun berdasarkan kajiankajian teori yang berkaitan dengan permasalahan. Cara yang digunakan untuk mengetahui tingkat validitas instrumen pada penelitian ini adalah menggunakan rumus korelasi product moment, sebagai berikut:

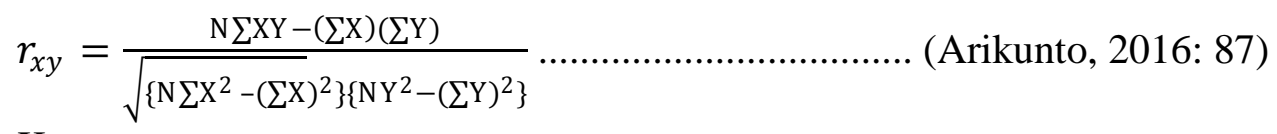

Keterangan : 


$$
\begin{array}{ll}
\mathrm{r}_{\mathrm{xy}} & =\text { Koefisien Korelasi antara } \mathrm{X} \text { dan } \mathrm{Y} \\
\mathrm{n} & =\text { Banyaknya Subjek } \\
\mathrm{x} & =\text { Nilai Pembanding } \\
\mathrm{y} & =\text { Nilai rata-rata }
\end{array}
$$

Setelah diketahui koefisien korelasi antara X dan Y, selanjutnya adalah menginterprestasikan besarnya koefisien korelasi dengan menggunakan kriteia sebagai berikut:

Tabel 3.5 Makna Koefisien Korelasi Product Moment

\section{Reliabilitas Tes}

\begin{tabular}{|c|c|}
\hline Angka Korelasi & Makna \\
\hline $0,800-1,000$ & Sangat Tinggi \\
\hline $0,600-0,800$ & Tinggi \\
\hline $0,400-0,600$ & Cukup \\
\hline $0,200-0,400$ & Rendah \\
\hline $0,000-0,200$ & Sangat Rendah \\
\hline
\end{tabular}

Reliabilitas alat penilaian adalah ketetapanalat tersebut dalam menilai apa yang dinilainya. Artinya kapan pun alat penilaian tersebut digunakan akan memberikan hasil yang relatif sama Sudjana (2009: 16). Untuk menguji reliabilitas tes pada penelitian ini yang digunakan adalah KR-20 dengan rumus sebagai berikut:

$\mathrm{r}_{11}=\left(\frac{n}{n-1}\right)\left(\frac{S^{2} \sum P q}{S^{2}}\right)$ (Arikunto, 2012:115)

Keterangan:

$r_{11}:$ Reliabilitas tes

$p \quad$ : Proporsi subyek yang menjawab benar

$q \quad$ : Proporsi subyek yang menjawab salah

$\sum p q \quad$ : Jumlah hasil perkalian antara $p$ dan $q$

$\mathrm{n} \quad$ : Banyak item

S : Standar deviasi tes

Interpretasi terhadap nilai koefisien korelasi $r_{11}$ digunakan kriteria sebagai berikut: $r_{11} \leq 0,20$ : reliabilitas sangat rendah

$0,20<r_{11} 0,40$

: reliabilitas rendah

$0,40<r_{11} \quad 0,70$

: reliabilitas sedang

$0,70<r_{11} 0,90$

: reliabilitas tinggi

$0,90<r_{11} 1,00$

: reliabilitas sangat tinggi

\section{Analisis Data}

Analisis data dan penelitian yang dilakukan adalah kualitatif dan kuantutatif. Kualitatif berupa pengisian lembar observasi terhadap pelaksanaan pelajaran yang akan dilakukan oleh guru. Kuantitatif dengan mengadakan tes awal dan tes akhir dalam proses pembelajaran pada masing-masing siklus. Hasil tes dianalisa per item soal.

\section{Hasil Pelaksanaan Pembelajaran}

Untuk mengetahui berhasil tidaknya tindakan yang dilakukan dan untuk mengetahui pelaksanaan pembelajaran, analisis data yang dapat dilakukan yaitu sebagai berikut:

1. Penilaian Aktivitas Guru 
Untuk mengetahui pelaksanaan pembelajaran aktivitas guru, digunakan rumus:

$\mathrm{HP}=\frac{\text { Total Skor (Perolehan ) }}{\text { Skor Maksimal }} \times 100 \%$

Tabel 3.8 Kriteria Penilaian dalam Pelaksanaan Pembelajaran

Aktivitas Guru

\begin{tabular}{|c|c|}
\hline Kriteria Penilaian & Keterangan \\
\hline $1=0-20$ & Sangat Kurang \\
\hline $2=21-40$ & Kurang \\
\hline $3=41-60$ & Cukup \\
\hline $4=61-80$ & Baik \\
\hline $5=81-100$ & Baik Sekali \\
\hline
\end{tabular}

Sumber: Piet (2013: 61)

\section{Penilaian Aktivitas peserta didik} rumus:

Untuk mengetahui pelaksanaan pembelajaran aktivitas siswa, digunakan $\mathrm{HP}=\frac{\text { Skor Perolehan }}{\text { Skor Maksimal }} \times 100$

Tabel 3.9 Kriteria Penilaian dalam Pelaksanaan Pembelajaran Aktivitas Peserta Didik

\begin{tabular}{|c|c|}
\hline Kriteria Penilaian & Keterangan \\
\hline $1=10-20$ & Sangat Kurang \\
\hline $2=30-49$ & Kurang \\
\hline $3=50-69$ & Cukup \\
\hline $4=70-89$ & Baik \\
\hline $5=90-100$ & Baik Sekali \\
\hline
\end{tabular}

Sumber: Asep Jihad (2012: 130)

\section{Ketuntasan Hasil Belajar Peserta Didik}

\section{a. Mencari Nilai Rata-rata}

Dalam mencari peningkatan hasil belajar peserta didik, digunakan rumus rata-rata yaitu:

$\mathrm{X}=\frac{\sum \mathrm{X}}{\mathrm{N}}$....... (Sudjana, 2009: 70)

Keterangan:

$\mathrm{X}=$ Nilai rata-rata

$\sum \mathrm{X}=$ Jumlah seluruh skor

$\mathrm{N}=$ Banyaknya objek

\section{b. Ketuntasan Individual}

Setiap peserta didik dikatakan tuntas belajarnya jika nilai yang diperoleh peserta didik telah mencapai $\mathrm{KKM}=80$, sesuai dengan yang ditetapkan sekolah.

Untuk menentukan ketuntasan belajar peserta didik dapat dihitung dengan menggunakan persamaan sebagai berikut: 
$\mathrm{KB}=\frac{\mathrm{T}}{\mathrm{Tt}} \mathrm{X} 100 \%$ (Trianto, 2010: 241)

Keterangan:

$\mathrm{KB}=$ Ketuntasan Belajar

$\mathrm{T}=$ Jumlah Skor yang diperoleh Peserta Didik

$\mathrm{Tt}=$ Jumlah Skor Total

\section{c. Ketuntasan Klasikal}

Untuk menghitung persentase ketuntasan belajar secara klasikal, digunakan rumus:

$\mathrm{P}=\frac{\sum \text { siswa yang tuntas belajar }}{\sum \text { siswa }} \mathrm{X} 100 \%$ (Zainal, dkk 2008: 41)

Kriteria tingkat keberhasilan belajar peserta didik dikelompokkan lima kategori, seperti yang terlihat pada tabel 3.8 di bawah ini.

Tabel 3.10 Kriteria Tingkat Keberhasilan Belajar Siswa dalam \%

\begin{tabular}{|c|c|}
\hline Tingkat Keberhasilan $(\%)$ & Keterangan \\
\hline$>80 \%$ & sangat tinggi \\
$60-76 \%$ & tinggi \\
$40-59 \%$ & sedang \\
$20-39 \%$ & rendah \\
$<20 \%$ & sangat rendah \\
\hline
\end{tabular}

Suatu kelas dikatakan tuntas belajar, jika dalam kelas tersebut $\geq 85 \%$ peserta didik yang telah tuntas belajarnya dari nilai KKM yang ditetapkan sekolah yaitu 80 .

\section{Indikator Kinerja Penelitian}

Penelitian tindakan kelas diasumsikan bila dilakukan tindakan perbaikan kualitas pembelajaran, sehingga akan berdampak terhadap perbaikan hasil belajar. Urutan indikator secara logika ilmiah disusun kembali menjadi:

1. Indikator keberhasilan kualitas proses pembelajaran minimal 'baik', baik dalam keaktifan peserta didik dalam memecahkan masalah yang dipelajari, kemampuan peserta didik dalam melakukan aktivitas belajar. Persentase yang ditargetkan adalah $80 \%$ dan cara mengukurnya adalah dengan mengamati peserta didik dalam proses pembelajaran dan menghitung siswa berapa yang aktif dan yang mampu dalam proses belajar tersebut.

2. Indikator keberhasilan hasil belajar secara klasikal minimal $75 \%$ dari jumlah peserta didik mencapai $\mathrm{KKM}=80$ dengan cara pengukuran adalah dengan hasil tes dalam mengerjakan soal kebebasan berorganisasi dan menghitung jumlah peserta didik yang dapat menjawab benar.

\section{Prosedur Penelitian}

Berdasarkan penelitian yang digunakan yaitu Penelitian Tindakan Kelas (PTK) maka desain penelitian ini seperti yang di kemukakan oleh Arikunto Dkk (2015:210) memiliki 4 tahapan yang dilakukan dalam melakanakan penelitian tindakan kelas yaitu: "perencanaan tindakan (planning), pelaksanaan tindakan (action), observasi (observation), dan refleksi (reflection 


\section{HASIL PENELITIAN DAN PEMBAHASAN}

Berdasarkan hasil dan pembahasan selama melaksanakan penelitian, maka dapat diketahui dengan menggunakan model Cooperative Learning tipe Numbered Heads Together (NHT),pada materi menyebutkan organisasi di lingkungan sekolah dan masyarakat dapat meningkatkan hasil belajar peserta didik. Hal ini disebabkan bahwa dengan menggunakan model Cooperative Learning tipe Numbered Heads Together (NHT)aktivitas belajar peserta didik menjadi meningkat, karena peserta didik lebih diajak berperan aktif dalam proses pemnbelajaran. Selain itu hasil observasi yang telah dilakukan dengaan menggunakanmodel Cooperative Learning tipe Numbered Heads Together (NHT),peserta didik lebih aktif dalam belajar dan memiliki tanggung jawab terhadap apa yang sudah dikerjakan.

Berdasarkan hasil observasi dari pengamatan kegiatan pembelajaran pada siklus I dan siklus II dengan rincian observasi kegiatan guru dan observasi kegiatan peserta didik adalah sebagai berikut:

1. Hasil observasi dari siklus I seperti yang telah dipaparkan diperoleh aktivitas peserta didik dengan hasil mencapai 58 sedangkan pada tahap siklus II observasi aktivitas peserta didik diperoleh hasil mencapai 92. Sesuai dengan presentase observasi yang sudah ditetapkan yaitu 80, pada proses penelitian ini sudah mencapai presentasi yang sudah ditetapkan dan pada tahap observasi setiap siklus mengalami peningkatan dan dikatakan kategori sangat baik.

2. Hasil observasi dari siklus I seperti yang telah dipaparkan diperoleh aktivitas guru dengan hasil mencapai 58 sedangkan pada tahap siklus II observasi aktivitas guru diperoleh hasil mencapai 90. Sesuai dengan presentase observasi yang sudah ditetapkan yaitu 80, pada proses penelitian ini sudah mencapai presentasi yang sudah ditetapkan dan pada tahap observasi setiap siklus mengalami peningkatan dan dikatakan kategori sangat baik.

3. Hasil belajar secara individu pada pretest yaitu yang tuntas belajar adalah 6orang peserta didik dan yang tidak tuntas adalah 31 orang peserta didik. Setelah dilakukan tindakan pada siklus I hasil belajarpeserta didik secara individu meningkat yaitu pada siklus I (postes) terdapat 15 orang peserta didik yang tuntas belajar dan yang tidak tuntas ada 22 orang peserta didik. Setelah dilakukan tindakan siklus belum mencapai presentase hasil belajar yang sudah ditetapkan yaitu 85\%. Maka dilakukan kembali tindakan perbaikan yaitu tindakan siklus II. Pada siklus II telah terjadi peningkatan yaitu yang tuntas belajar adalah 33 orang peserta didik dan yang tidak tuntas belajar adalah 4 orang peserta didik. Sesuai dengan presentase hasil belajar yang sudah ditetapkan yaitu $85 \%$, pada proses penelitian ini sudah mencapai presentasi yang sudah ditetapkan dan pada tahap hasil belajar setiap siklus mengalami peningkatan dan dikatakan kategori sangat baik.

4. Hasil belajar secara klasikalpada pratest yaitu yang tuntas belajar adalah 6 $(16,21 \%)$ orangpeserta didik dan yang tidak tuntas adalah $31(83,79 \%)$ orang peserta didik. Setelah dilakukan tindakan pada siklus I hasil belajar peserta didik secara klasikal meningkat yaitu pada siklus I terdapat 15 (40,54\%)orang peserta didik yang tuntas belajar dan yang tidak tuntas ada 
$22(59,46 \%)$ orang peserta didik. Setelah dilakukan tindakan siklus belum mencapai presentase hasil belajar yang sudah ditetapkan yaitu $85 \%$. Maka dilakukan kembali tindakan perbaikan yaitu tindakan siklus II. Pada siklus II telah terjadi peningkatan yaitu yang tuntas belajar adalah $33(89,18 \%)$ orang peserta didik dan yang tidak tuntas belajar adalah 4 (10,82\%)orang peserta didik. Sesuai dengan presentase hasil belajar yang sudah ditetapkan yaitu $85 \%$, pada proses penelitian ini sudah mencapai presentasi yang sudah ditetapkan dan pada tahap hasil belajar setiap siklus mengalami peningkatan dan dikatakan kategori sangat baik.

5. Hasil rata-rata pada kegiatan pratest didapat nilai rata-rata yaitu 59,18 sedangkan pada siklus I terdapat nilai rata-rata yaitu 73,24 dan pada tahap siklus II didapat nilai rata-rata yaitu 85,94 . Pada proses penelitian ini pada setiap siklus sudah mengalami peningkatan dan dikatakan kategori sangat baik.

\section{PENUTUP Simpulan}

Berdasarkan hasil penelitian dan pembahasan ini dapat disimpulkan sesuai dengan perumusan masalah bahwa proses pelaksanaan pembelajaran dengan menggunakan model Cooperative Learning Tipe Numbered Heads Together (NHT)pada mata pelajaran Pendidikan Kewarganegaraan (PKn) materi menyebutkan organisasi di lingkungan sekolah dan masyarakat dapat meningkatkan hasil belajar peserta didik, hipotesis tindakan yang ada pada bab II dapat dibuktikan, yaitu sebagai berikut:

1. Adanya peningkatan hasil belajar Pendidikan Kewarganegaraan (PKn) pada materi menyebutkan organisasi di lingkungan sekolah dan masyarakat dengan menggunakan model Cooperative Learning Tipe Numbered Heads Together (NHT)pada peserta didik kelas V-B SD Budi Murni 6 Medan Tahun Pembelajaran 2016-2017 yaitu pada pelaksanaan prates rata-ratayang diperoleh sebesar 59,18 dan ketuntasan klasikalnya 16,21, siklus I dengan rata-rata sebesar 73,24 dan ketuntasan klasikalnya 40,54\%, sedangkan pada siklus II dengan rata-rata sebesar 85,94 dan ketuntasan klasikalnya 89,18\%. Hal tersebut sesuai dengan kriteria ketuntasan yang telah ditetapkan.

2. Adanya peningkatan aktivitas peserta didik dalam pembelajaran Pendidikan Kewarganegaraan (PKn) pada materi menyebutkan organisasi di lingkungan sekolah dan masyarakat dengan menggunakan model Cooperative Learning Tipe Numbered Heads Together (NHT)pada peserta didik kelas V-B SD Budi Murni 6 Medan yaitu pada siklus I sebesar 58 dan pada siklus II sebesar 92.

\section{Implikasi}

Hasil yang diperoleh dari penelitian ini menunjukkan ada peningkatan hasil belajar peserta didik, mata pelajaran Pendidikan Kewarganegaraan (PKn) dengan materi menyebutkan organisasi di lingkungan sekolah dan masyarakat denganmenggunakan model Cooperative Learning tipe Numbered Heads Together (NHT).Hal ini memberikan penjelasan bahwa dengan menggunakan model Cooperative Learning tipe Numbered Heads Together (NHT), merupakan salah satu faktor untuk meningkatkan hasil belajar peserta didik.Hal ini dilihat 
dari hasil belajar peserta didik selama proses penelitian dilakukan mengalami peningkatan dan tujuan pembelajaran dapat tercapai dan terlaksana dengan baik.Tindak mengajar yang telah dilakukan guru dan tindak belajar yang dilakukan peserta didik memberikan gambaran seberapa jauh pemahaman peserta didik terhadap penguasaan materi.Tindak mengajar dan tindak belajar dapat juga digunakan untuk mengukur kemampuan atau keberhasilan guru dalam menyampaikan materi pelajaran kepada peserta didik.

Dengan demikian, apabila model pembelajaran yang kurang tepat digunakan pada saat pelaksanaan pembelajaran berlangsung, maka hasil belajar peserta didik pun akan rendah dan juga kegiatan pembelajaran pun tidak akan terlaksana dengan baik. Oleh karena itu, implikasi hasil penelitian ini bagi pendidikan adalah:

1. Bagipeserta didik, dengan menggunakan model Cooperative Learning tipe Numbered Heads Together (NHT)membawa dampak positif terhadap hasil belajarpeserta didik yakni terjadi peningkatan pada hasil belajar pada mata pelajaran Pendidikan Kewarganegaraan (PKn).

2. Bagi guru, dengan menggunakanmodel Cooperative Learning tipe Numbered Heads Together (NHT)pada mata pelajaranPendidikan Kewarganegaraan (PKn) dapat digunakan guru sebagai acuan dalam meningkatkan hasil belajar peserta didik.

\section{Keterbatasan Penelitian}

Dalam penelitian ini terdapat keterbatasan yang diharapkan akan membuka kesempatan bagi peneliti lainnya untuk melakukan penelitian sejenis yang akan berguna bagi perluasan wawasan keilmuan. Keterbatasan dalam penelitian ini adalah:

1. Pengambilan subjek dan sampel penelitian dipilih sendiri dan berasal dari satu sekolah yaitu SD Budi Murni 6 Medan, sehingga hasil penelitian ini belum tentu sesuai dengan sekolah lain dan daerah lain yang memiliki karakteristik yang berbeda dengan sekolah yang saat ini diteliti.

2. Penelitian ini hanya terbatas pada penerapan model Cooperative Learning tipe Numbered Heads Together (NHT)untuk meningkatkan hasil belajar peserta didik pada mata pelajaran Pendidikan Kewarganegaraan (PKn) dengan materi menyebutkan organisasi di lingkungan sekolah dan masyarakat. Banyak faktor yang mempengaruhi hasil belajar peserta didik misalnya lingkungan sekolah, kemampuan guru, lingkungan masyarakat, keluarga, kesehatan peserta didik, dan kemampuan peserta didik dalam mengikuti pembelajaran.

\section{Saran}

a. Bagi Guru

Guru diharapkan saat melakukan proses belajar mengajar, menggunakan model pembelajaran Cooperative Learning tipe Numbered Heads Together (NHT)sebagai alternatif dalam kegiatan pembelajaran karena model ini dapat meningkatkan hasil belajar peserta didik khususnya pada mata pelajaran Pendidikan Kewarganegaraan (PKn) dengan materi menyebutkan organisasi di lingkungan sekolah dan masyarakat. Sebelum pelaksanaan model Cooperative Learning tipe Numbered Heads Together (NHT)hendaknya guru mempersiapkan 
segala sesuatu yang dibutuhkan baik alat dan bahan yang menunjang proses pembelajaran akan berlangsung dengan baik.

b. Bagi Sekolah

Bagi pihak sekolah hendaknya dapat menambah pengadaan sarana dan prasarana pelajaran yang dapat meningkatkan proses belajar mengajar dengan menggunakan model-model pembelajaran. Kepala sekolah agar kiranya dapat melakukan pelatihan kepada guru-guru tentang penggunaan model-model pembelajaran yang ddapat meningkatkan kemampuan guru sehingga hasil belajar peserta didik dapat ditingkatkan.

c. Bagi Peneliti Berikutnya

Bagi peneliti berikutnya jika ingin melakukan jenis penelitian yang sama sebaiknya dilaksanakan lebih dari 1 siklus agar tercapai hasil belajar yang lebih efektif dan efisien. Bagi peneliti berikutnyahendaknya lebih kritis dalam menghadapi masalah yang muncul dalam dunia pendidikan, khususnya dalam masalah pembelajaran sehingga hasil penelitian inidapat dijadikan sebagai referensi dalam memberikan informasi tentang pelaksanaan pembelajaran

\section{DAFTAR PUSTAKA}

Adiguna, dkk. 2015. Buku Bina PKn untuk SD dan MI Kelas V. Medan: Bina Media Perintis.

Aqib, Zainal. 2008. Penelitian Tindakan Kelas. Bandung: Yrama Widya.

Arikunto, Suharsimi. 2012. Dasar-dasar Evaluasi Pendidikan. Jakarta: Bumi Aksara.

Arikunto, Suharsimi. 2016. Dasar-dasar Evaluasi Pembelajaran. Jakarta: Bumi Aksara.

. 2015. Penelitian Tindakan Kelas. Jakarta: Bumi Aksara.

Danim, Sudarwan. 2010. Perkembangan Peserta Didik. Bandung: Alfabeta.

Ginting, Susanna. 2016. Meningkatkan Hasil Belajar Siswa pada Mata Pelajaran IPA dengan Menggunakan Model Pembelajaran Numbered Heads Together di Kelas V SD Negeri 101771 Tembung Kecamatan Percut Sei Tuan Tahun Ajaran 2015/2016. Medan.

Hamalik, Oemar. 2014. Kurikulum dan Pembelajaran. Jakarta: Bumi Aksara. Hamdani. 2017. Strategi Belajar Mengajar. Bandung: Pustaka Setia.

Hamruni. 2013. Strategi Pembelajaran. Yogyakarta: Insan Madani.

Horiah, dkk. 2015. Upaya Meningkatkan Hasil Belajar Matematika melalui Penerapan Pembelajaran Kooperatif tipe Numbered Heads Together (NHT) Siswa Kelas III SDN 016 Sekeladi.

http://jurnal.fkip.uns.ac.id/indeks.php/pgsdkebumen/article/view/2392.

Istarani. 2012. 58 Model Pembelajaran Inovatif. Medan: Media Persada.

Istarani dan Intan Pulungan. 2015. Ensiklopedi Pendidikan. Medan: Larispa.

Jihad dan Abdul Haris. 2012. Evaluasi Pembelajaran. Jakarta: Multi Presindo.

Khairani, Makmur. 2013. Psikologi Pendidikan. Yogyakarta: Aswaja Presindo.

Kurniasih \& Sani. 2016. Ragam Pengembangan Model Pembelajaran untuk Peningkatan Profesionalitas Guru. Yogyakarta: Kata Pena.

Ngalimun. 2015. Strategi dan Model Pembelajaran. Banjarmasin: Aswaja Pressindo. 
Purba, Lelita. 2016. Meningkatkan Hasil Belajar Siswa dengan Menggunakan Model Pembelajaran Kooperatif Tipe Numbered Heads Together (NHT) pada Mata Pelajaran IPS Kekas V SD Negeri 010086 Kisaran Tahun Ajaran 2015/2016. Medan.

Sahertian, Piet. 2010. Konsep Dasar dan Tehnik Supervisi Pendidikan dalam Rangka Pengembangan Sumber Daya Manusia. Jakarta: Rineka Cipta.

Sagala, Syaiful. 2008. Konsep dan Makna Pembelajaran. Bandung: Alfabeta.

Sanjaya, Wina. 2011. Strategi Pembelajaran Berorientasi Standar Proses Pendidikan. Jakarta: Kencana.

Shoimin, Aris. 2016. 68 Model Pembelajaran Inovatif dalam Kurikulum 2013. Yogyakarta: Ar-Ruzz Media.

Sianipar, Juni. 2016. Meningkatkan Hasil Belajar Siswa dengan Menggunakan Model Cooverative Learning Tipe Numbered Heads Together (NHT) pada Materi Pokok Operasi Hitung Campuran Bilangan Bulat di Kerlas IV SD Swasta Betania Medan Tahun Ajaran 2015/2016. Medan.

Sudjana, Nana. 2009. Penilaian Hasil Proses Belajar Mengajar. Bandung: PT Remaja Rosdakarya.

Sugiono. 2012. Metode Penelitian Pendekatan Kuantitatif, Kualitatif dan R\&D. Bandung. Alfabeta.

Susanto, Ahmad. 2016. Teori Belajar dan Pembelajaran di Sekolah Dasar. Jakarta: Prenadamedia Group.

Tampubolon, Saur.M. 2014. Penelitian Tindakan Kelas. Jakarta: Erlangga.

Thayeb, dkk. 2006. Buku Pendidikan Kewarganegaraan untuk SD Kelas V. Jakarta: Penerbit Erlangga.

Trianto. 2009. Mendesain Model Pembelajaran Inovatif-Progresif. Jakarta: Kencana.

Usman, Mohammad Uzer. 2010. Menjadi Guru Profesional. Bandung: PT Remaja Rosdakarya. 